形状，適応部位等について数多くの報告もあり各施設で もルチンワークの中て使用されていると思われるか， そ の取扱いが簡単で，確実性が高してとが要求されるが, 各自が補償フィル夕の使用を積極的に行なうことが重要 であると考える、今回の発表は成人を対象としたと考え られるが小韭への検討も加えて欲しい。 また被曝線量に ついて記録系の違いてよるものおよび補償フィルタの有 無によるあのとを明確にして欲しかった。発表時のます さから内容のまとまりを欠いたてとは残念である.研究 発表は自分の発表内容を聞いている人に判かりゃすく伝 えることも重要であり，原稿とスライドとの関連や，聞 き取り易い言葉 (話し言葉) にも十分気を配って欲しい。

演題 47 は, 人工関節置換術のための骨計測法としてQ 撮影方法およびX線スケールを考案し実用に役立ててい るてとを発表した。手術に関してより正確な情報を得る ととあ大事な要素である. 又,，幾何学的条件などの再現 性のある撮影法も術前, 術後の観察の中で要求されると 考えられる.

单純撮影に関しては, 撮影法, 撮影条件, 補助具等に つて基礎晲研究・検討から，いかにして診断能の向上 に役立てるか追求されていかね林ならない，今後も研究 を重ね，診断的応用に至るものも含め研讃されるととを 望む.

\section{単純撮影 -3}

座長 小目敬寿 (帝京大学)

\section{8. 耳鼻科領域における撮影法 Chaussé III 法の検討 につWt}

$$
\begin{array}{r}
\text { 金沢医科大学病院中央放射線部 } \\
\text { O定免茂昭・宮崎滋夫 } \\
\text { 魚公儀一・飛田 明 }
\end{array}
$$

Chaussé III 法はX線入射角度を変化させるととによ り, 耳小骨のみではなく, 多くの内耳, 中耳の器管を観 察できるのではないかと考え，X線入射角度について検 討した:

〔結果〕耳小骨, 鼓室, 上鼓室, 内耳道, 前庭, 螖牛, 半規管が最も良く観察できたX線入射角度は，X線管球 は $\mathrm{OM}$ 線记対して足方へ 15 度, 頭部は，非検側に矢状面 を20度から25度傾けたときとなった。とのX線中心線は 外耳孔中心より約 $2 \mathrm{~cm}$ 上方を通るように，頭頂より斜 入させる.

また Stenvers 法と比較しても, Chaussé III 法の方が 多くの器管を観察するのに適しているととあわかった。

49. 個人差を考慮した Sonnenkalb 法の開発（第一報）
慶灾義塾大学娭院放射線技術室

○森 俊・斉藤 厳・西平源幸 岡部幸司・諸田勝広・栗原政油 東洋公睬衛生学院 鍵田政雄

従来, Sonnenkalb法は，原法通りに撮影されてきたが， X-P は外耳道・内耳道が重複しないのが現実であった。 そてで，患者の個人差を考えた撮影法の検討をおこなっ た. 頭部の dry-bone で基礎実験を, 次に患者 58例より 内・外耳道貫通線とドイッ水平面，矢状面に対する傾既 角度を計測し, 頭部の最大頭蓋長径，両側頭骨距離，そ の比をはかりーつのデータを基に 150 例の臨床的撮影を してみた。その結果, 頭部の最太頭蓋長径, 両側頭骨間 距離を計測し, 長巾率を求める事により撮影以前に $\left(15^{\circ}\right.$, $\left.15^{\circ}\right)$ 法, $\left(20^{\circ}, 10^{\circ}\right)$ 法, $\left(20^{\circ}, 5^{\circ}\right)$ 法を選択して撮影する 事は, 内・外耳道重複を考える上に非常佂値の高いもの と考えた。

\section{0. 顔面神経ブロックにおける荎乳突孔撮影の検討} 神戸大学医学部附属病院中央放射線部 ○川瀬修三，古東正宜・桜井富美子 村上 徹・山内 孝・垣鍔房穗

〔目的】顔面神経ブロック時の茥乳突，孔内のブロッ ク針位置確認のための, 荎乳突, 孔撮影法の検討, 並び に,ブロック針先端権認のための立体撮影の適用性を検 討した.

〔方法】 Philips 社製ニューロダイアグノーストN 装 置のユニバーサルアーム機構を利用し，頭部ファントム によって，軸位撮影の基準線 OM line に対する至適角 度を決め, 臨床上で，立体撮影や側卧位軸位撮影と共に， それらの応用度を試した。

[結果] 軸位撮影の OM line 飞対する至適角度は足 万より70度から75度でった。立体撮影す軸方向より見 て管球に対しブロ.ック針の縦方向の位置確認に有用であ った. 側臥位撮影も当ブロック法に置き再現性のある, 且つ, 患者の負担の少ない適正撮影法であった。

\section{1. 上顎洞 $\mathrm{X}$ 線写真陰影の定量的測定}

東京大学医学部付属病院中央放射線部

$$
0 \text { 二村 样 }
$$

東京大学医学部付属病院耳鼻咽喉科 洲崎春海

東京大学医学部付属病院中央放射線部 佐竹芳朗

小西六写真工業(株) 中丸三次

[目的] 副鼻腔炎症例で副鼻腔単純X線写真洞内陰影 の濃淡を定量的江測定するため基準ウェッジを試作し， 